\title{
Influence of management on plankton community of fishponds during the dry and rainy seasons
}

\author{
Influência do manejo sobre a comunidade planctônica de \\ viveiros de piscicultura durante os períodos seco e chuvoso
}

Lúcia Helena Sipaúba Tavares ${ }^{1}$, Rodrigo Ney Millan ${ }^{2}$ and Atanásio Alves do Amaral ${ }^{3}$

\author{
${ }^{1}$ Centro de Aquicultura, Universidade Estadual Paulista - UNESP, \\ CEP 14884-900, Jaboticabal, SP, Brazil \\ e-mail: sipauba@caunesp.unesp.br
}
${ }^{2}$ Faculdade de Ciências Agrárias e Veterinárias, Universidade Estadual Paulista - UNESP,
CEP 14884-900, Jaboticabal, SP, Brazil
e-mail: rodrigomillan@yahoo.com.br

${ }^{3}$ Instituto Federal do Espírito Santo - Ifes, CEP 25520-000, Alegre, ES, Brazil
e-mail: atmaral@gmail.com

\begin{abstract}
Aim: The present investigation aims at evaluating attention to the occurrence and abundance of planktonic communities in fishponds and their relationships to the management employed; Methods: Seven fishponds $\left(V_{1}-V_{7}\right)$ fertilized with different treatments were analyzed by monthly sampling, taken between July and December/07, during both dry and rainy seasons; Results: Euglenophyceae and Chlorophyceae were most representative during the studied period. In the fishpond with organic fertilizer Cyanobacteria was more than 65 and $90 \%$ of total phytoplankton abundance in September and August, mainly represented by Microcystis sp. (14,595 and 22,500 ind.L-1 respectively). An inverse relationship occurred between Copepoda and Cladocera, and Copepoda and Rotifera were present in all fishponds during the both seasons. Diversity $\left(\mathrm{H}^{\prime}\right)$ and species richness was low and equitability indices generally showed the highest values for zooplankton. The lowest values were observed for phytoplankton during the rainy season; Conclusions: The use of organic fertilizer and the random emptying of the fishponds affected directly and species diversity and richness, with dominance of Cyanobacteria emphasizing the need to adopt a management technique to increase fishponds productivity and consequently, fish production.
\end{abstract}

Keywords: phytoplankton, zooplankton, fishponds, management.

Resumo: Objetivo: O presente estudo objetivou avaliar a ocorrência e abundância da comunidade planctônica em viveiros de piscicultura em função do manejo adotado; Métodos: Foram estudados sete viveiros $\left(\mathrm{V}_{1}-\mathrm{V}_{7}\right)$ com diferentes tratamentos de fertilização, com amostras realizadas mensalmente de julho a dezembro/07, em duas épocas do ano: seca e chuva; Resultados: Em geral, Euglenophyceae e Chlorophyceae foram as mais representativas ao longo do período estudado. No viveiro com fertilizante orgânico, Cyanobacteria representou mais de 65 e $90 \%$ do total de organismos fitoplanctônicos ocorrido em setembro e agosto representado principalmente por Microcystis sp. (14.595 e 22.500 ind. $\mathrm{L}^{-1}$, respectivamente). Relaçáo inversa foi observada entre Copepoda e Cladocera, porém Copepoda juntamente com Rotifera estiveram presentes em todos os viveiros nas duas estaçóes. A diversidade ( $\left.\mathrm{H}^{\prime}\right)$ e riqueza de espécies apresentaram baixos valores e, o índice de equitabilidade, em geral, foi elevado para o zooplâncton. Os valores mais baixos de equitabilidade para o fitoplâncton foram observados durante a estação chuvosa; Conclusóes: $\mathrm{O}$ uso de fertilizante orgânico e o esvaziamento aleatório dos viveiros influenciaram diretamente na diversidade e riqueza de espécies, com dominância de Cyanobacteria, enfatizando a necessidade de adotar uma metodologia de manejo para aumentar a produtividade dos viveiros e consequentemente, a produçáo de peixes.

Palavras-chave: fitoplâncton, zooplâncton, viveiros, manejo. 


\section{Introduction}

Fishponds are environments completely managed and handled by man, with constant addition of fertilizer in order to increase the productivity and profitability of the system. Exploitation of fisheries resources in Brazil has been carried out in the absence of adequate limnological knowledge of fishponds.

Farming activities can cause important impacts on the environments due to the discharge of wastewater into streams and rivers and creeks (Konsowa, 2007). Fertilization is by far the most useful technique that provides the essential nutrients for aquatic biota that serve either directly or indirectly as fish food (Begum et al., 2007).

Fertilization (both inorganic and organic) has great implications for the increase of phytoplankton and zooplankton biomass thus affecting directly the fish biomass (Santeiro et al., 2006; Vega et al., 2007). Both quality and quantity abundance of plankton communities in fishponds are of great importance in managing successful aquaculture operations, and they vary from location and pond to pond within the same location even under similar ecological conditions (Bhuiyan et al., 2008).

Plankton distribution and abundance are affected by season, physical and chemical parameters, water movement, soil, and biological factors (Davies et al., 2009).

Therefore the present investigation aims at analysing attention to the occurrence and abundance of phytoplankton and zooplankton in fishponds and their relationships with the management practices employed.

\section{Materials and Methods}

\subsection{Area and sampling sites}

The study was carried out at the "Instituto Federal do Espírito Santo" (Ifes) ”- Campus Alegre, Alegre, ES, Brazil, situated at $20^{\circ} 45^{\prime} \mathrm{S}$ and $41^{\circ} 27^{\prime} \mathrm{E}$ at a mean altitude of $108 \mathrm{~m}$. According to the Köppen classification, the region climate is AW, subtropical, relatively dry in the winter (June to September) and rainy in the summer (October to December), with mean yearly temperature $23.4^{\circ} \mathrm{C}$ and mean yearly rainfall $1,325.9 \mathrm{~mm}$.

The Ifes - Campus Alegre fish farm, totaling 4 ha of flooded land, comprises thirty-seven earthen ponds with independent water supply. The choice and of the seven fish ponds $\left(\mathrm{V}_{1}-\mathrm{V}_{7}\right)$ to be sampled was based on morphometry, location and usage availability. Areas of the fishponds varied between
$710\left(\mathrm{~V}_{2}\right)$ and $6,550 \mathrm{~m}^{2}\left(\mathrm{~V}_{7}\right)$, and mean depth was $1.50 \mathrm{~m}$. Fishponds' water supply comes from the waterfall Braúnas, $4 \mathrm{~km}$ from the fishponds area, and is channeled to the ponds by underground tubes. Continuous water flow provided a $5 \%$ daily rate of rearing volume. The fishponds were populated with matrinxã (Brycon cephalus) in $\mathrm{V}_{1 ;}$ catfish (Ictalurus punctatus) in $\mathrm{V}_{2}$; catfish (Ictalurus punctatus) and grass carp (Ctenopharyngodon idella) in $\mathrm{V}_{3}$; fries of silver carp (Hypophthalmichthys molitrix) and pacu (Piaractus mesopotamicus) in $\mathrm{V}_{4}$; pacu fries (Piaractus mesopotamicus), grass carp (Ctenopharyngodon idella) and silver carp (Hypophthalmichthys molitrix) in $\mathrm{V}_{5}$; pacu fries (Piaractus mesopotamicus), grass carp (Ctenopharyngodon idella), silver carp (Hypophthalmichthys molitrix), big-head carp (Aristichthys nobilis) and catfish (Ictalurus punctatus) in $\mathrm{V}_{6}$; pacu fries (Piaractus mesopotamicus), grass carp (Ctenopharyngodon idella), and big-head carp (Aristichthys nobilis) in $\mathrm{V}_{7}$, at a density of approximately 0.34 fish per $\mathrm{m}^{2}$ (Figure 1 ).

Management the ponds occurred randomly since they were fertilized according to material availability. The following management has been adopted throughout the study:

- $\mathrm{V}_{1}$ to $\mathrm{V}_{3}=$ diet with ration at $32 \%$ crude protein;

- $\mathrm{V}_{4}$ and $\mathrm{V}_{5}=$ lime spreading; fortnightly fertilization with urea between March and July; rations with $32 \%$ crude protein also provided;

- $\mathrm{V}_{6}$ = lime spreading; fertilization with pig dung and urea; and

- $\mathrm{V}_{7}=$ lime spreading; fertilization with chicken dung and rations at $32 \%$ crude protein. Livestock inner parts were provided at irregular intervals throughout the study period. Sampling for abiotic and biotic variables was conducted once a month, from July to December/07. During this period, both dry and rainy seasons were experienced.

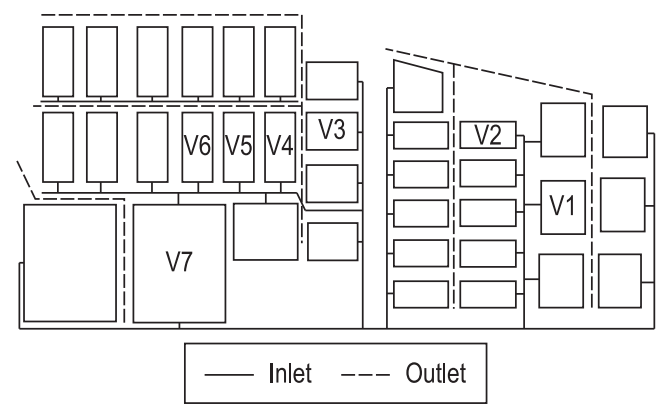

Figure 1. Cross-section of fish ponds of "Instituto Federal do Espirito Santo - Campus Alegre", showing the sampled ponds $\left(\mathrm{V}_{1}-\mathrm{V}_{7}\right)$ in the station. 


\subsection{Plankton}

Sampling for plankton was done using a Van Dorn bottle filtering a volume of $5 \mathrm{~L}$ for phytoplankton and $12 \mathrm{~L}$ to zooplankton. The plankton samples was filtered with $25 \mu \mathrm{m}$ and $68 \mu \mathrm{m}$ mesh nets, and preserved in Lugol iodine solution and formalin (4\%), respectively for phytoplankton and zooplankton. The concentrated preserved plankton samples were analyzed using a Sedgewick-Rafter counting cell with a compound binocular microscope (Option, TIM-107) at 200x magnification. In addition Cladocera and Copepoda, were counted in a reticulated chamber using a TIM 2B stereoscopic microscope. Numerical densities data were expressed in individuals. $\mathrm{L}^{-1}$ (ind. $\mathrm{L}^{-1}$ ) and percentage abundance (\%). Approximately 400 specimens of the most abundant species were counted for a $10 \%$ more a less precision, and a $95 \%$ confidence interval (Bicudo, CEM. and Bicudo, DC., 2004). The diversity index (H'), equitability and richness (total number of species) were used to analyze the diversity of phytoplankton and zooplankton between seasons and among ponds (Shannon and Weaver, 1963; Odum and Barrett, 2007). The ecological index values were obtained by estimating the mean values obtained for each season (dry and rainy) at each analyzed pond (V1 to V7). Occurrence frequency of different taxa was calculated according to the following classification: constant ( $50 \%$ or over); common (between 10 and 50\%); rare (between 1 and 10\%) (Sampaio et al., 2002). The criteria of Lobo and Leighton (1986) were also applied to describe species dominance and abundance. Species were considered abundant when the number of specimens was higher than mean density of all species; and dominant when the density was higher than $50 \%$ of the total number of specimens.

\subsection{Limnological variables}

Water samples were collected at a depth of 0.10 $\mathrm{m}$. The transparency was measured by Secchi disk, $\mathrm{pH}$ was measured by model Q-400A Quimis $\mathrm{pH}$ meter. Chlorophyll- $a$ was evaluated according to Nusch (1980) and nutrients according to Koroleff (1976) and Golterman et al. (1978).

\subsection{Statistical analysis}

The Kruskal-Wallis test (Siegel, 1975) was applied, to the physical and chemical variables and plankton population, to compare sites and seasons, and interactions between them. The significance level was taken as $\mathrm{p}=0.05$.

\section{Results}

During the period under analysis, the zooplanktonic community was represented by 10 taxa: 5 Rotifera, 3 Cladocera and 2 Copepoda (Table 1). Although Copepoda species were found in all fishponds, only Argyrodiaptomus sp. was dominant in $\mathrm{V}_{2}$; as a rule, Copepoda nauplii were abundant and/or dominant. Argyrodiaptomus sp. and Mesocyclops sp. were present in both seasons and Copepoda nauplii were abundant during the dry season and dominant in the rainy one. Conochilus sp., was the only dominant representative of the group Rotifera in $\mathrm{V}_{2}$ during the rainy season and $\mathrm{V}_{5}$ during the dry season. An inverse relationship between Moina sp. and Conochilus sp. occurred, whereupon, when one was dominant in a particular pond, the other was absent. Of the Cladocera, only Moina sp. was dominant in $\mathrm{V}_{7}$

Table 1. Composition (+, -), frequency (\%) of occurrence (F) and abundance (A-d) of zooplankton taxa during the dry (D) and rainy $(R)$ seasons in fishponds $\left(V_{1}-V_{7}\right)$, where: $+=$ present; - = absent; $C=$ constant; $c=$ common; $\mathrm{r}=$ rare; $\mathrm{A}=$ abundant; $\mathrm{d}=$ dominant.

\begin{tabular}{|c|c|c|c|c|c|c|c|c|c|c|c|c|c|c|c|c|c|c|c|c|c|}
\hline \multirow[t]{2}{*}{ Taxa } & \multicolumn{3}{|c|}{$V_{1}$} & \multicolumn{3}{|c|}{$\mathrm{V}_{2}$} & \multicolumn{3}{|c|}{$\mathrm{V}_{3}$} & \multicolumn{3}{|c|}{$\mathrm{V}_{4}$} & \multicolumn{3}{|c|}{$V_{5}$} & \multicolumn{3}{|c|}{$V_{6}$} & \multicolumn{3}{|c|}{$V_{7}$} \\
\hline & $D$ & $\mathrm{R}$ & $\mathrm{F}$ & D & $\mathrm{R}$ & $\mathrm{F}$ & D & $\mathrm{R}$ & $\mathrm{F}$ & D & $\mathrm{R}$ & $\mathrm{F}$ & D & $\mathrm{R}$ & $\mathrm{F}$ & D & $\mathrm{R}$ & $\mathrm{F}$ & $\mathrm{D}$ & $\mathrm{R}$ & $\mathrm{F}$ \\
\hline \multicolumn{22}{|l|}{ Rotifera } \\
\hline Brachionus sp. & + & + & C & + & + & C & - & A & c & - & + & c & - & - & & - & + & C & - & - & \\
\hline Filinia sp. & + & - & c & - & - & & - & + & c & - & - & & - & - & & + & - & C & - & - & \\
\hline Lecane sp & - & - & & - & - & & - & - & & - & - & & - & - & & + & - & C & + & - & C \\
\hline Polyarthra sp. & + & + & C & - & - & & + & + & c & + & + & c & - & - & & + & - & C & A & A & C \\
\hline Conochilus sp. & - & - & & + & $d$ & c & - & - & & A & - & c & $d$ & + & c & + & - & C & - & - & \\
\hline \multicolumn{22}{|l|}{ Cladocera } \\
\hline Ceriodaphnia sp. & - & - & & - & - & & - & - & & - & - & & - & - & & + & - & C & - & - & \\
\hline Diaphanosoma sp. & - & A & c & - & + & c & - & + & c & - & - & & - & - & & - & + & C & - & A & c \\
\hline Moina sp. & + & + & C & + & - & c & - & + & c & + & - & C & - & + & c & A & - & C & $d$ & - & c \\
\hline \multicolumn{22}{|l|}{ Copepoda } \\
\hline Argyrodiaptomus sp. & + & A & c & $d$ & + & C & A & + & c & - & + & c & + & + & c & - & + & C & + & - & c \\
\hline Mesocyclops sp. & $A$ & A & C & + & - & c & + & + & c & - & A & c & + & + & $C$ & + & - & C & - & A & C \\
\hline nauplii & A & + & C & + & + & C & A & A & C & $d$ & + & $C$ & A & $d$ & C & A & $d$ & $C$ & A & - & C \\
\hline
\end{tabular}


during the dry season, and occurred in all fishponds, being present in both seasons in $\mathrm{V}_{1}$. Among the Rotifera species, Brachionus sp. and Polyarthra sp. were abundant during the rainy season $\left(\mathrm{V}_{3}\right)$ and the latter abundant in both seasons $\left(\mathrm{V}_{7}\right)$ (Table 1). Ceriodaphnia sp. was the only species found in a single fishpond $\left(\mathrm{V}_{6}\right)$ during the dry season associated with high content of nitrate $\left(652 \mu \mathrm{g} . \mathrm{L}^{-1}\right)$, relatively low phosphorus content $\left(49 \mu \mathrm{g} . \mathrm{L}^{-1}\right)$ and food consisting mainly of Ankistrodesmus sp. and Scenedesmus sp. (Tables 1 and 2).

Copepoda was the most abundant group in $\mathrm{V}_{5}$ to $\mathrm{V}_{7}$ after the October discharge, and Cladocera was abundant, mainly Moina sp. (884 ind. $\mathrm{L}^{-1}$ ), in $\mathrm{V}_{2}$ during September. When Argyrodiaptomus sp. was more abundant (an herbivorous species), in $V_{1}$ in December, and $\mathrm{V}_{4}$ and $\mathrm{V}_{6}$ in September, densities of Copepoda and Cladocera were similar. However, when Mesocyclops sp. (carnivorous species) was more abundant, Cladocera species were virtually absent in the environment. Copepoda and Rotifera occurred in all fishponds during the two seasons (Figure 2).

The phytoplankton community was represented by 33 taxa with a high number of Chlorophyceae species (9). Pediastrum duplex, occurred in both seasons, in all fish ponds, and was dominant or abundant in the environment. Further, Scenedesmus sp. also occurred in all fishponds, albeit

Table 2. Composition (+,-), frequency of occurrence (F) and abundance (A-d) of phytoplankton genera and species found during the dry $(D)$ and rainy $(R)$ seasons in the sampled fishponds $\left(V_{1}-V_{7}\right)$, where: + = present; - = absent; $\mathrm{C}=$ constant $\mathrm{c}=$ common; $\mathrm{r}=$ rare; $\mathrm{A}=$ abundant; $\mathrm{d}=$ dominant.

\begin{tabular}{|c|c|c|c|c|c|c|c|c|c|c|c|c|c|c|c|c|c|c|c|c|c|}
\hline \multirow[t]{2}{*}{ Taxa } & \multicolumn{3}{|c|}{ V1 } & \multicolumn{3}{|c|}{$\mathrm{V} 2$} & \multicolumn{3}{|c|}{ V3 } & \multicolumn{3}{|c|}{ V4 } & \multicolumn{3}{|c|}{ V5 } & \multicolumn{3}{|c|}{ V6 } & \multicolumn{3}{|c|}{ V7 } \\
\hline & $D$ & $\mathrm{R}$ & $\mathrm{F}$ & $D$ & $\mathrm{R}$ & $F$ & $D$ & $\mathrm{R}$ & $\mathrm{F}$ & $\mathrm{D}$ & $\mathrm{R}$ & $\mathrm{F}$ & $D$ & $\mathrm{R}$ & $\mathrm{F}$ & $D$ & $\mathrm{R}$ & $\mathrm{F}$ & $D$ & $\mathrm{R}$ & $\mathrm{F}$ \\
\hline \multicolumn{22}{|l|}{ Bacillariophyceae } \\
\hline Asterionella sp. & + & - & C & - & - & & - & - & & - & - & & - & - & & + & - & C & - & - & \\
\hline Gyrosigma sp. & - & - & & + & + & $c$ & - & - & & - & - & & + & - & C & + & - & C & + & + & C \\
\hline Navicula sp. & $A$ & + & C & + & $A$ & C & + & - & C & + & + & C & - & - & & A & + & C & - & + & C \\
\hline Surirella sp. & $A$ & - & C & + & + & C & + & - & C & - & - & & - & - & C & - & - & & - & + & $\mathrm{C}$ \\
\hline \multicolumn{22}{|l|}{ Chlorophyceae } \\
\hline Ankistrodemus sp. & - & - & & + & + & C & - & - & & - & - & r & - & - & r & + & - & C & - & - & \\
\hline Chodatellopsis sp. & - & - & & + & + & C & - & - & & - & + & C & - & - & C & - & - & & - & - & \\
\hline Desmodesmus armatus (Chord.) Hegewald & A & - & C & - & - & & - & - & & - & - & & - & - & & - & - & & - & - & \\
\hline Eutetramorus sp. & + & + & C & A & A & C & + & + & C & - & - & & - & - & & + & - & C & - & + & C \\
\hline Pediastrum duplex Meyen & A & A & C & + & A & C & A & A & C & $d$ & + & C & + & + & C & $d$ & + & C & A & + & C \\
\hline Scenedesmus acuminatus (Largerheim) Chodat & - & + & C & - & + & C & - & + & C & - & + & C & - & - & & - & $A$ & C & - & - & \\
\hline Scenedesmus linearis (Komárek) & A & - & C & - & - & & - & + & C & - & - & & - & - & & - & - & & + & + & C \\
\hline Scenedesmus quadricauda (Turpin) Brébison & - & + & r & - & - & & - & - & & - & + & C & - & - & & - & + & $\mathrm{C}$ & - & - & \\
\hline Scenedesmus sp. & + & - & r & + & + & C & A & + & C & + & + & C & A & - & C & + & - & C & + & + & r \\
\hline \multicolumn{22}{|l|}{ Cyanobacteria } \\
\hline Anabaena sp. & - & - & & - & $A$ & C & - & - & & - & - & & - & - & & - & - & & - & - & \\
\hline Aphanizomenon sp. & + & + & C & - & + & C & + & + & C & - & - & & - & + & $\mathrm{C}$ & + & - & $\mathrm{C}$ & + & + & $\mathrm{C}$ \\
\hline Lyngbya sp. & - & - & & - & + & C & + & - & C & - & + & C & - & - & & - & - & & - & - & \\
\hline Merismopedia sp. & - & - & & - & + & C & - & - & & - & - & & - & - & & - & - & & - & - & \\
\hline Microcystis sp. & + & + & C & + & - & C & A & + & C & - & + & $\mathrm{C}$ & - & - & & A & - & $\mathrm{C}$ & A & + & C \\
\hline Pseudanabaena sp. & - & - & & - & - & & + & - & C & - & - & & - & - & & - & - & & + & - & $\mathrm{C}$ \\
\hline \multicolumn{22}{|l|}{ Euglenophyceae } \\
\hline Euglena acus Ehrenberg & A & A & C & + & $A$ & C & + & + & C & - & + & C & - & - & & - & + & C & - & - & \\
\hline Euglena sp. & - & + & C & + & - & C & A & A & C & + & $d$ & C & A & A & C & + & - & $\mathrm{C}$ & A & A & C \\
\hline Phacus longicauda (Ehrenberg) Dujardin & + & A & C & - & + & C & A & - & C & - & + & r & + & - & C & + & - & C & - & - & \\
\hline Phacus pleuronectes (Muller) Dujardin & - & + & r & - & + & C & - & + & C & - & - & & - & - & & + & $d$ & C & - & - & \\
\hline Strombomonas acuminatus (Schmarda) Deflandre & + & + & C & - & + & C & + & + & C & A & + & C & A & + & C & A & + & C & + & + & C \\
\hline Trachelomonas pulchella Drezepolski & - & - & & - & - & & - & - & & - & - & & - & + & C & - & - & & - & - & \\
\hline Trachelomonas sp. & + & + & C & - & - & & - & $A$ & C & - & $A$ & $\mathrm{C}$ & + & $d$ & C & - & $A$ & C & - & A & $\mathrm{C}$ \\
\hline \multicolumn{22}{|l|}{ Eustigmatophyceae } \\
\hline Pseudostaurastrum sp. & - & - & & + & + & C & - & - & & - & - & & - & - & & - & - & & - & - & \\
\hline \multicolumn{22}{|l|}{ Zygnematophyceae } \\
\hline Closterium sp. & - & - & & + & - & $\mathrm{C}$ & - & - & & - & - & C & - & - & & + & - & & - & - & \\
\hline Cosmarium sp. & - & - & & - & - & & - & - & & - & - & & - & - & & + & - & C & - & - & \\
\hline Pleurotaenium sp. & - & - & & - & - & & - & - & & + & - & C & + & - & C & - & - & & + & - & C \\
\hline Spirogyra sp. & - & - & & - & - & & + & - & C & - & - & & - & - & & - & - & & + & - & $\mathrm{C}$ \\
\hline Staurastrum tetracerum Ralfs & + & + & C & + & + & C & + & - & C & + & + & C & - & - & & - & - & $\mathrm{C}$ & - & - & \\
\hline Staurodesmus sp. & - & - & & - & - & & - & - & & - & - & & - & - & & - & + & C & - & - & \\
\hline
\end{tabular}



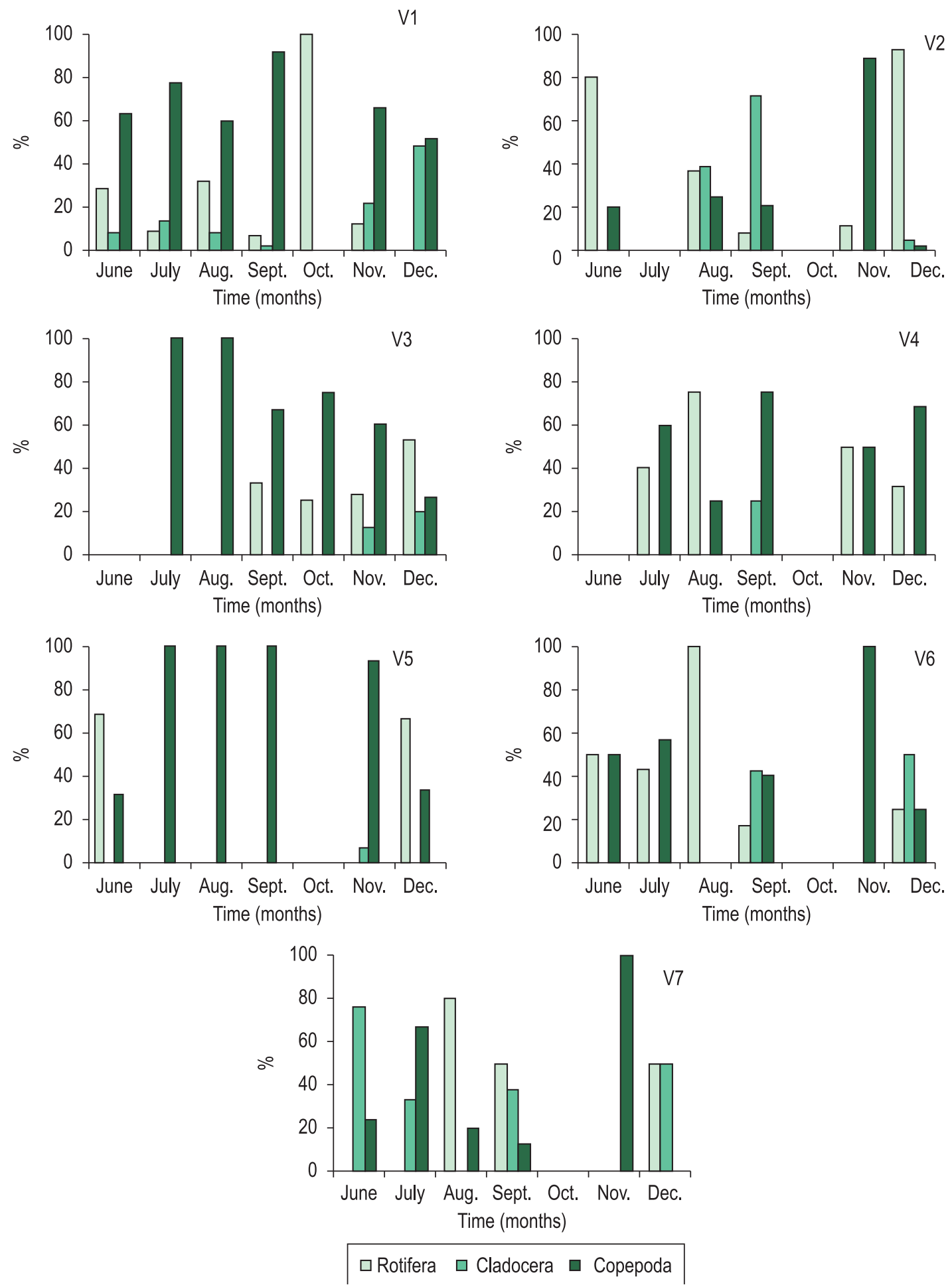

Figure 2. Relative abundance (\%) of zooplankton found in the fishponds $\left(\mathrm{V}_{1}-\mathrm{V}_{7}\right)$ during the study period, where: Time (months) $=$ Months.

absent in fishponds $\mathrm{V}_{1}, \mathrm{~V}_{5}$ and $\mathrm{V}_{6}$ during the rainy season (Table 2).

Euglena sp. and Strombomonas acuminatus, among the Euglenophyceae species, occurred in all fishponds, with the former dominant in $\mathrm{V}_{4}$ during the rainy season. Phacus pleuronectes and Trachelomonas sp. were also dominant during the rainy season, respectively in $\mathrm{V}_{6}$ and $\mathrm{V}_{5}$. All the Euglenophyceae species were abundant or dominant throughout the study period, with the exception of Trachelomonas pulchella, which was only found in $\mathrm{V}_{5}$ during the rainy season (Table 2; Figure 3).

Zygnematophyceae was represented by six low density taxa with main occurrence in the dry season. 

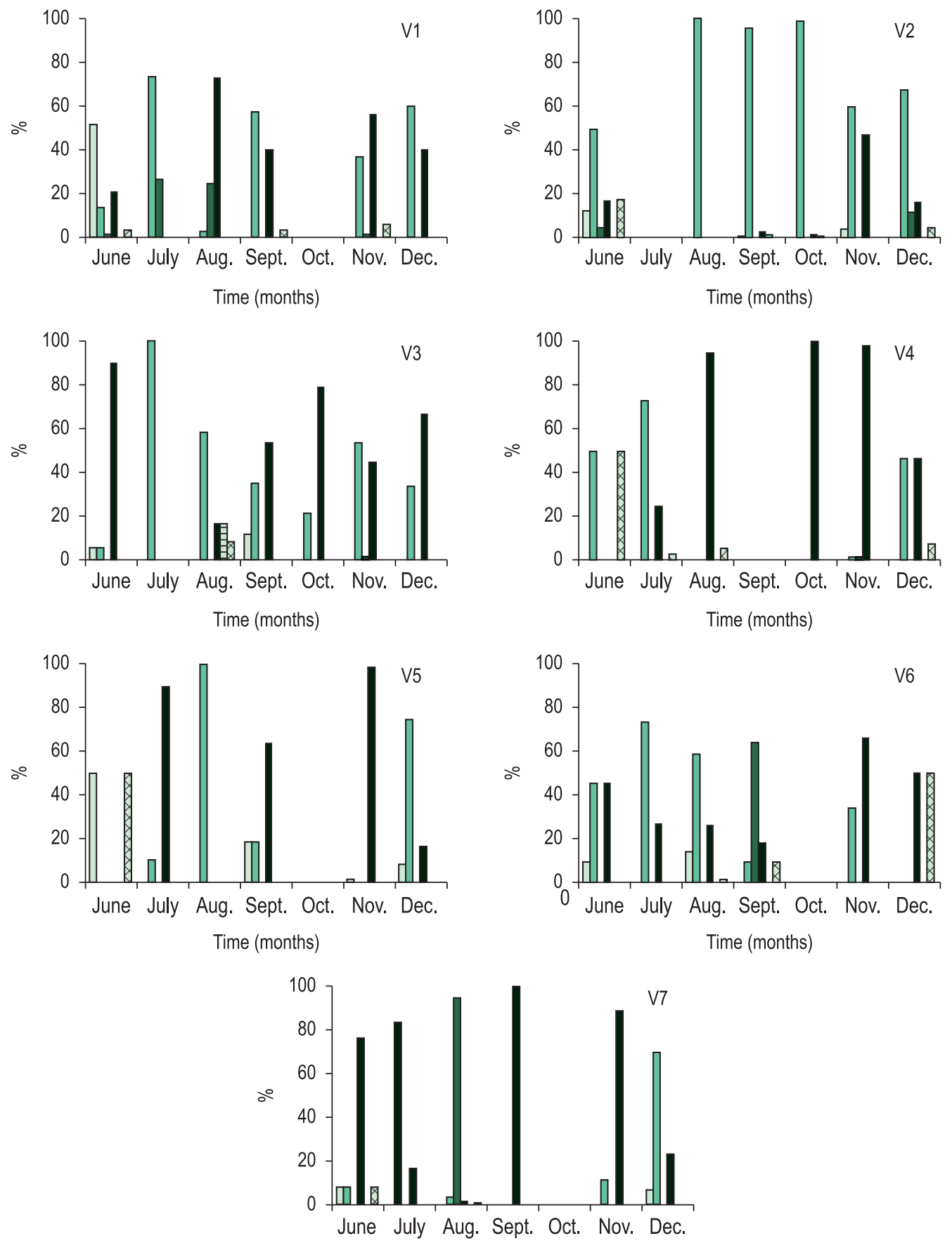

Time (months)

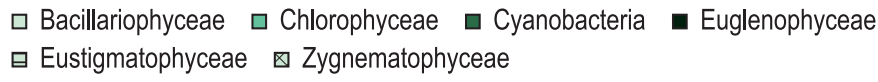

Figure 3. Relative abundance (\%) of phytoplankton found in the fishponds $\left(V_{1}-V_{7}\right)$ during the study period, where: Time (months) $=$ Months.

The exceptions were Staurastrum tetracerum which occurred during both seasons and Staurodesmus sp. which occurred only in $\mathrm{V}_{6}$ during the rainy season. Eustigmatophyceae was represented by the single taxon Pseudostaurastrum sp. which occurred during both seasons only in $V_{2}$, associated with low nitrate and nitrite concentrations $\left(<11 \mu \mathrm{g} . \mathrm{L}^{-1}\right)$ and high concentrations of orthophosphate and total phosphorus $\left(>31 \mu \mathrm{g} . \mathrm{L}^{-1}\right)$. Cyanobacteria were represented by 6 species, generally represented abundant, constant or common species in the fishponds. Merismopedia sp. occurred only in $\mathrm{V}_{2}$ 
during the rainy season. The density of Cyanobacteria was low in $\mathrm{V}_{5}\left(20\right.$ ind. $\left.\mathrm{L}^{-1}\right)$ represented mainly by Aphanizomenon sp. (Table 2; Figure 3).

Euglenophyceae was dominant during the rainy season and Chlorophyceae constant during the dry season (Table 2). Inadequate management water discharge and consequent filling up occurred in $\mathrm{V}_{2}$ in July and in $\mathrm{V}_{5}$ to $\mathrm{V}_{7}$ in October, these factors could have caused Euglenophyceae dominance in $\mathrm{V}_{5}$ to $\mathrm{V}_{7}$ in November. Cyanobacteria dominance (>90\%), chiefly represented by Microcystis sp. with 22,500 ind. $\mathrm{L}^{-1}$ (Figure 3), occurred in $\mathrm{V}_{7}$ during August (dry season).

Diversity $\left(\mathrm{H}^{\prime}\right)$ of the plankton community was low, tending towards a decrease from $V_{1}$ to $V_{5}$ in the case of phytoplankton and from $V_{3}$ to $V_{5}$ in the case of zooplankton during the rainy season. The species richness was low with the highest values (19) being observed in $V_{2}$ during the rainy season. The values of species richness were lowest for the zooplankton community. Equitability indices generally showed the highest values for zooplankton. The lowest values were observed in the $\mathrm{V}_{4}(0.30)$ and $\mathrm{V}_{5}(0.31)$ for phytoplankton during the rainy season (Figure 4).

The phytoplankton community was not represented in $\mathrm{V}_{1}$ during October, with only one Rotifera species, Polyarthra sp. (16 ind.L $\mathrm{L}^{-1}$ ), being reported Moina sp. (17 ind. $\mathrm{L}^{-1}$ ) and Copepoda nauplii (51 ind. $\mathrm{L}^{-1}$ ) among the zooplankton, occurred in $\mathrm{V}_{4}$ during September, in the absence of phytoplankton. When zooplankton did not occur in $\mathrm{V}_{3}$ during June, Euglenophyceae presented a high percentage $(89.4 \%)$, consisting of Euglena sp. (36,140 ind.L $\left.\mathrm{L}^{-1}\right)$, Strombomonas sp. (8,340 ind.L $\left.\mathrm{L}^{-1}\right)$ and Euglena acus (2,780 ind. $\left.\mathrm{L}^{-1}\right)$. The same pattern was reported in $\mathrm{V}_{4}$ during October when two algae, Trachelomonas sp. (705,500 ind.L $\left.\mathrm{L}^{-1}\right)$ and Euglena sp. (232,400 ind. $\left.\mathrm{L}^{-1}\right)$, occurred, and also, during June, when Closterium sp. and Scenedesmus sp., both with abundance of 5,355 ind. $\mathrm{L}^{-1}$ were recorded (Figures 1 and 2; Tables 1 and 2).

The phytoplankton and zooplankton communities did not differ between fishponds and seasons ( $p>0.05)$ during the study period.

The $\mathrm{pH}$ values varied from 6.4 to 8.3 without differences $(p>0.05)$ between fish ponds and seasons. Transparency values were significantly different $(\mathrm{p}<0.05)$ among the fishponds reaching the highest value $(1.00 \mathrm{~m})$ in $\mathrm{V}_{5}$ in both seasons. Lowest transparency was observed in the fishponds $\mathrm{V}_{1}, \mathrm{~V}_{3}, \mathrm{~V}_{4}$ and $\mathrm{V}_{7}$ and was more associated with management than with the content of Chlorophyll-a
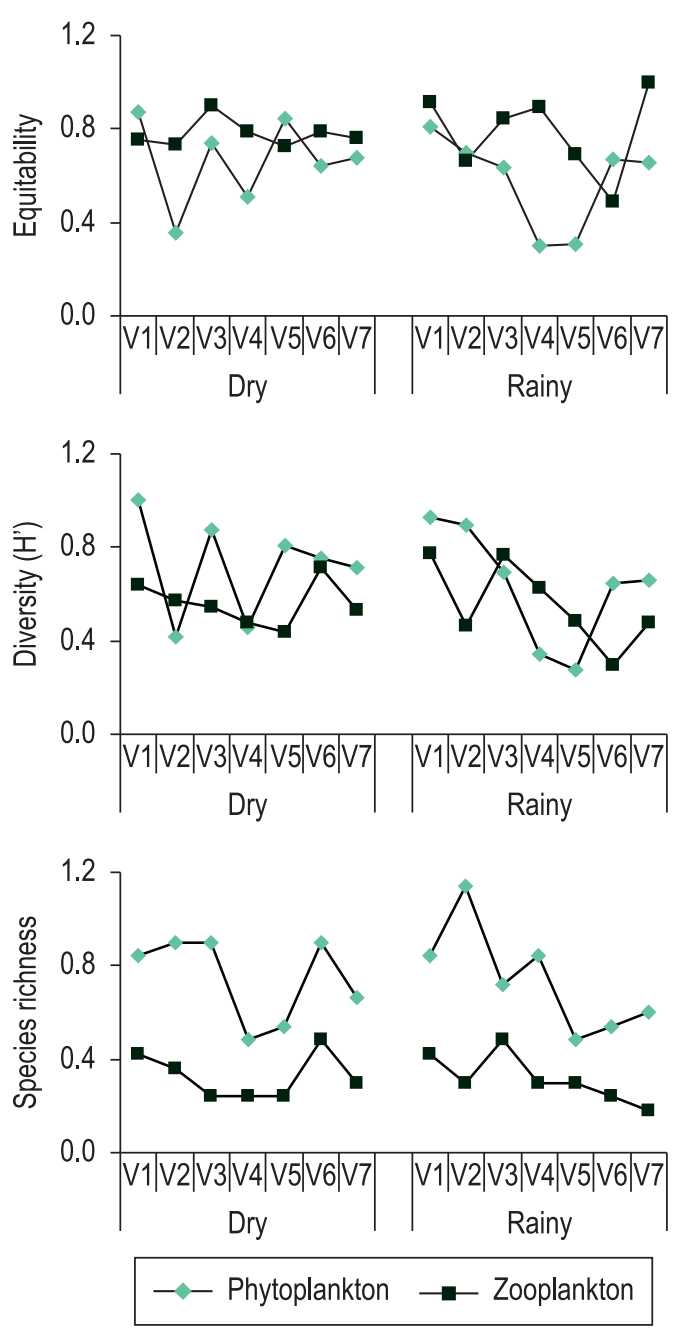

Figure 4. Seasonal values of species equitability, diversity (bits.ind ${ }^{-1}$ ) and richness of phytoplankton and zooplankton during the study period in the different fishponds $\left(\mathrm{V}_{1}-\mathrm{V}_{7}\right)$.

(6 to $59 \mu \mathrm{g} . \mathrm{L}^{-1}$ ). The transparency was higher in $\mathrm{V}_{5}$ during the dry season $(1.00 \mathrm{~m})$ and in $\mathrm{V}_{6}(0.98 \mathrm{~m})$ during the rainy season, coinciding with lowest Chlorophyll- $a$ concentration (8.4 and $6.0 \mu \mathrm{g} . \mathrm{L}^{-1}$, respectively) in the fishponds (Table 3 ).

Among nitrogen compounds, ammonia values were highest and differed significantly among fishponds and seasons $(\mathrm{p}<0.05)$. In fishponds $V_{1}$, $\mathrm{V}_{6}$ and $\mathrm{V}_{7}$ during the dry season, nitrate displayed the highest values and differed significantly from the other fishponds $(\mathrm{p}<0.05)$. The total phosphorus and orthophosphate did not differ between fishponds and seasons $(\mathrm{p}>0.05)$ (Table 3).

\section{Discussion}

The management of fertilization in the fishponds was carried out according to the availability of material to be used for this purpose. This 
Table 3. Average, minimum and maximum values of nutrients ( $\left.\mu \mathrm{g} . \mathrm{L}^{-1}\right)$, Chlorophyll- $a\left(\mu \mathrm{g} . \mathrm{L}^{-1}\right), \mathrm{pH}$ and transparency $(\mathrm{m})$ in the fishponds $\left(\mathrm{V}_{-}-\mathrm{V}_{7}\right)$ during the dry $(\mathrm{D})$ and rainy $(\mathrm{R})$ seasons.

\begin{tabular}{|c|c|c|c|c|c|c|c|c|c|c|c|c|c|c|}
\hline \multirow[t]{2}{*}{ Parameters } & \multicolumn{2}{|c|}{$V_{1}$} & \multicolumn{2}{|c|}{$V_{2}$} & \multicolumn{2}{|c|}{$\mathrm{V}_{3}$} & \multicolumn{2}{|c|}{$\mathrm{V}_{4}$} & \multicolumn{2}{|c|}{$V_{5}$} & \multicolumn{2}{|c|}{$\mathrm{V}_{6}$} & \multicolumn{2}{|c|}{$\mathrm{V}_{7}$} \\
\hline & $D$ & $\mathrm{R}$ & D & $\mathrm{R}$ & D & $\mathrm{R}$ & D & $\mathrm{R}$ & $\mathrm{D}$ & $\mathrm{R}$ & D & $\mathrm{R}$ & D & $\mathrm{R}$ \\
\hline Ammonia & $\begin{array}{c}55 \\
12-81\end{array}$ & $\begin{array}{c}63 \\
39-93\end{array}$ & $\begin{array}{c}136 \\
9-347\end{array}$ & $\begin{array}{c}83 \\
68-102\end{array}$ & $\begin{array}{c}165 \\
6-472\end{array}$ & $\begin{array}{c}129 \\
122-136\end{array}$ & $\begin{array}{c}94 \\
22-155\end{array}$ & $\begin{array}{c}98 \\
71-142\end{array}$ & $\begin{array}{c}125 \\
22-366\end{array}$ & $\begin{array}{c}97 \\
95-102\end{array}$ & $\begin{array}{c}461 \\
57-1,651\end{array}$ & $\begin{array}{c}92 \\
59-124\end{array}$ & $\begin{array}{c}107 \\
47-151\end{array}$ & $\begin{array}{c}132 \\
38-281\end{array}$ \\
\hline Nitrite & $\begin{array}{c}4.2 \\
3.7-5.1\end{array}$ & $\begin{array}{c}4.5 \\
4-4.9\end{array}$ & $\begin{array}{c}5 \\
3.5-6.3\end{array}$ & $\begin{array}{c}4.4 \\
3.8-5.1\end{array}$ & $\begin{array}{c}4.5 \\
3.4-5.4\end{array}$ & $\begin{array}{c}4.8 \\
4.4-5.2\end{array}$ & $\begin{array}{c}4.7 \\
3.5-5.9\end{array}$ & $\begin{array}{c}4.9 \\
4.6-5.2\end{array}$ & $\begin{array}{c}8.4 \\
3.8-20.8\end{array}$ & $\begin{array}{c}6 \\
5.1-7.1\end{array}$ & $\begin{array}{c}16.6 \\
3.5-52\end{array}$ & $\begin{array}{c}5.6 \\
3.7-9\end{array}$ & $\begin{array}{c}5.8 \\
5.2-7\end{array}$ & $\begin{array}{c}4 \\
4-4\end{array}$ \\
\hline Nitrate & $\begin{array}{c}307 \\
68-883\end{array}$ & $\begin{array}{c}59 \\
21-37\end{array}$ & *5.7 & $\begin{array}{c}11 \\
1-21\end{array}$ & $\begin{array}{c}26 \\
1.4-51\end{array}$ & ${ }^{*} 0.5$ & $\begin{array}{c}39 \\
16-63\end{array}$ & $\begin{array}{c}30 \\
11-48\end{array}$ & $\begin{array}{c}109 \\
8-188\end{array}$ & $\begin{array}{c}27 \\
2-53\end{array}$ & *652 & - & $\begin{array}{c}162 \\
16-351\end{array}$ & $\begin{array}{c}67 \\
21-113\end{array}$ \\
\hline Orthophosphate & $\begin{array}{c}28 \\
18-52\end{array}$ & $\begin{array}{c}21 \\
13-36\end{array}$ & $\begin{array}{c}31 \\
18-54\end{array}$ & $\begin{array}{c}67 \\
23-153\end{array}$ & $\begin{array}{c}21 \\
10-35\end{array}$ & $\begin{array}{c}22 \\
7-43\end{array}$ & $\begin{array}{c}29 \\
17-46\end{array}$ & $\begin{array}{c}34 \\
21-44\end{array}$ & $\begin{array}{c}21 \\
12-31\end{array}$ & $\begin{array}{c}32 \\
21-54\end{array}$ & $\begin{array}{c}19 \\
18-21\end{array}$ & $\begin{array}{c}25 \\
23-27\end{array}$ & $\begin{array}{c}22 \\
18-24\end{array}$ & $\begin{array}{c}22 \\
20-25\end{array}$ \\
\hline $\begin{array}{l}\text { Total } \\
\text { Phosphorus }\end{array}$ & $\begin{array}{c}85 \\
47-115\end{array}$ & $\begin{array}{c}85 \\
60-109\end{array}$ & $\begin{array}{c}74 \\
55-98\end{array}$ & $\begin{array}{c}135 \\
60-250\end{array}$ & $\begin{array}{c}76 \\
57-93\end{array}$ & $\begin{array}{c}83 \\
57-109\end{array}$ & $\begin{array}{c}71 \\
52-85\end{array}$ & $\begin{array}{c}95 \\
90-104\end{array}$ & $\begin{array}{c}53 \\
17-71\end{array}$ & $\begin{array}{c}95 \\
76-125\end{array}$ & $\begin{array}{c}49 \\
17-71\end{array}$ & $\begin{array}{c}101 \\
71-131\end{array}$ & $\begin{array}{c}71 \\
55-85\end{array}$ & $\begin{array}{c}62 \\
57-68\end{array}$ \\
\hline Chlorophyll-a & $\begin{array}{c}48.8 \\
22-62\end{array}$ & $\begin{array}{c}16.7 \\
11-25\end{array}$ & $\begin{array}{c}20.5 \\
14-28\end{array}$ & $\begin{array}{l}18.6 \\
6-25\end{array}$ & $\begin{array}{c}58.6 \\
45-92\end{array}$ & $\begin{array}{l}42.8 \\
6-70\end{array}$ & $\begin{array}{c}32.8 \\
17-53\end{array}$ & $\begin{array}{c}31 \\
14-56\end{array}$ & $\begin{array}{c}8.4 \\
3-17\end{array}$ & $\begin{array}{c}40 \\
14-67\end{array}$ & $\begin{array}{l}34.9 \\
8-59\end{array}$ & $\begin{array}{c}6 \\
6-6\end{array}$ & $\begin{array}{c}30 \\
8-59\end{array}$ & $\begin{array}{c}59 \\
6-95\end{array}$ \\
\hline Transparency & $\begin{array}{c}0.25 \\
0.20-0.30\end{array}$ & $\begin{array}{c}0.19 \\
0.18-0.19\end{array}$ & $\begin{array}{c}0.55 \\
0.40-0.62\end{array}$ & $\begin{array}{c}0.32 \\
0.33-0.63\end{array}$ & $\begin{array}{c}0.15 \\
0.12-0.25\end{array}$ & $\begin{array}{c}0.21 \\
0.12-0.25\end{array}$ & $\begin{array}{c}0.41 \\
0.28-0.55\end{array}$ & $\begin{array}{c}0.39 \\
0.13-0.80\end{array}$ & $\begin{array}{c}0.95 \\
0.75-1.00\end{array}$ & $\begin{array}{c}0.76 \\
0.27-1.00\end{array}$ & $\begin{array}{c}0.59 \\
0.38-0.72\end{array}$ & $\begin{array}{c}0.98 \\
0.98-0.98\end{array}$ & $\begin{array}{c}0.45 \\
0.30-0.51\end{array}$ & $\begin{array}{c}0.21 \\
0.13-0.30\end{array}$ \\
\hline $\mathrm{pH}$ & $\begin{array}{c}7.1 \\
6.4-8.3\end{array}$ & $\begin{array}{c}7.7 \\
7.3-8.1\end{array}$ & $\begin{array}{c}7.2 \\
6.9-7.6\end{array}$ & $\begin{array}{c}7.7 \\
7.6-7.9\end{array}$ & $\begin{array}{c}7.2 \\
7.0-7.5\end{array}$ & $\begin{array}{c}7.3 \\
7.0-7.5\end{array}$ & $\begin{array}{c}7.3 \\
6.9-7.4\end{array}$ & $\begin{array}{c}7.3 \\
7.3-7.3\end{array}$ & $\begin{array}{c}7.2 \\
6.5-7.8\end{array}$ & $\begin{array}{c}7.4 \\
7.1-8.0\end{array}$ & $\begin{array}{c}7.5 \\
7.0-7.7\end{array}$ & $\begin{array}{c}7.4 \\
7.3-7.5\end{array}$ & $\begin{array}{c}7.2 \\
6.5-7.5\end{array}$ & $\begin{array}{c}7.3 \\
7.2-7.4\end{array}$ \\
\hline
\end{tabular}

randomness reflected directly on the biotic and abiotic factors of the studied fishponds. In fishponds $\mathrm{V}_{6}$ and $\mathrm{V}_{7}$ where organic fertilization was applied (pig and chicken dung), the content of ammonia, nitrite and nitrate were high during the dry season and the total phosphorus and Chlorophyll- $a$ were high during the rainy season. Transparency values seemed to have been directly affected by climatic factors, and displayed very low values ( 0.13 to $0.30 \mathrm{~m}$ ) during the rainy season, perhaps associated with the presence of allocthonous material in the fish ponds.

The overall objective of fertilizer application is to increase the productivity of the fish pond and both organic and inorganic fertilizers can be used. While the inorganic fertilizers mainly increase the quantity of primary producers, organic fertilizers such as dung of cattle, pig and poultry, biomass slurry, compost and other livestock wastes serve as substrates for stimulating abundant growth of zooplankton, insect larvae and other forms of fish food organisms (Begum et al., 2007).

In the studied fish farm, the values determined for species richness and diversity were not high for neither phytoplankton or zooplankton, due to lack of fertilization methodology and the fact that the ponds were randomly emptied during the year.

Euglenophyceae increase coincides with high $\mathrm{pH}$ levels, high orthophosphate and total phosphorus concentrations and high levels of organic matter (Taniguchi et al., 2005). Euglenophyceae and Cyanobacteria are better adapted to environments with high levels of nitrogen and organic matter, such as fishponds (Pereira et al., 2001). In this study, in the fishponds fertilized with organic manure, Cyanobacteria was more abundant and represented
$60 \%$ of the total phytoplankton abundance found in September in $\mathrm{V}_{6}$ and $91.4 \%$ of total found in August in $\mathrm{V}_{7}$.

Crustacea (Copepoda, Cladocera) and Rotifera can be abundant in manure treated ponds. The zooplankton production in ponds under going manure treatments increased rapidly from around the $3^{\text {rd }}$ week of fertilization and also that water quality determined the species composition in the ponds (Santeiro et al., 2006; Begum et al., 2007).

Inorganic fertilizer can also influence the dynamics of the zooplanktonic community leading to high population abundances of small Cladocera and Cyclopoida (Vega et al., 2007). In the present study, the fishponds $\mathrm{V}_{4}$ and $\mathrm{V}_{5}$ that were fertilized with urea demonstrated high abundance of Copepoda, represented mainly by Copepoda nauplii. In fishponds $V_{1}$ and $V_{3}$ where only ration was added, without fertilizer addition, the Cladocera species were present in almost every month, but were abundant only in fishpond $\mathrm{V}_{1}$. According to Okojin and Obi (1999), organic fertilizer increases the growth of smaller sized zooplankton (Rotifera) while inorganic fertilizer favors growth of bigger sized zooplankton (Copepoda), the later resulting in more favorable conditions for fish culture. Predominance of juvenile organisms (nauplii) among crustaceans may be associated with the management adopted (fertilization) (Begum et al., 2007).

There was a greater Copepoda constancy during the dry period which was associated with a total lack or low abundance of Cladocera $\left(\mathrm{V}_{1} ; \mathrm{V}_{3}-\mathrm{V}_{5}\right)$. The use of organic fertilization in $\mathrm{V}_{7}$ could have decreased species richness and, consequently, favored the occurrence of opportunist species. Several authors have observed that trophic state decisively affects 
the distribution of Rotifera species. Some species of this group such as Keratella quadrata and Brachionus angularis are found more frequently in water with high nutrient levels (Vega et al., 2007).

In fishpond $\mathrm{V}_{6}$ with organic fertilizer, Rotifera species during the dry season were the most abundant, especially in August when they represented 100\% of the zooplanktonic population. At the beginning of the rainy season in October, in $\mathrm{V}_{1}$, Rotifera also represented $100 \%$ of the total zooplanktonic with great relative abundance of Polyarthra sp. When the same treatment was applied to fishponds $V_{1}$ to $\mathrm{V}_{3}$ (addition of ration only); $\mathrm{V}_{4}$ and $\mathrm{V}_{5}$ (lime and urea), and $V_{6}$ and $V_{7}$ (organic fertilizer), no seasonal patterns were recorded in species fluctuation in the populations of either phytoplankton or zooplankton. In this case, the random emptying of the fishponds to harvest the fish, as well as the continuous water flow could have directly affected diversity and species richness.

Rotifera abundance may be inversely related to abundances of Protozoa and Copepoda (Kyewalyanga and Mwandya, 2004). Such an inverse relationship (between Rotifera and Copepoda) was also observed in the present study, when Copepoda was more abundant during the dry season.

Due to low water depth the artificial fishponds environment can be greatly affected by local climatic factors. However, in fishpond systems in which proper management fails to occur, especially with regard to stocking density, fertilization, feed (ration), type of breeding species, control of water flow in the fishpond and adequate treatment of inflowing water human activities can be the main factors influencing the abiotic and biotic conditions of these systems.

Basic information regarding phytoplankton and zooplankton, and the relationships of these organisms with management and water quality is a key factor in devising a successful fish farm strategy (Kyewalyanga and Mwandya, 2004). This is because plankton density, composition and succession patterns can greatly affect production of the earlier development stages of fish.

The results of the present study are in agreement with other analyses on the effects of management and environment variables on plankton in ponds with regard to extensive and policulture fish farming. In the present study, inorganic fertilizer addition and use of ration alone promoted better water quality, and the dominance of Chlorophyceae and Euglenophyceae species among the phytoplankton, and Rotifera and Copepoda especially the calanoid, Argyrodiaptomus sp., among the zooplankton compared to the fishponds treated with organic fertilizer. The latter presented elevated relative abundances of Cyanobacteria. In addition, the continuous water flow, a common practice in the Southeast region of the country, associated with the fact that in the studied fish farm the ponds were randomly emptied, seemed to have influenced diversity and species richness. Therefore, it is recommended that the management should be standardized in order to increase system productivity and consequently, fish production.

\section{References}

BEGUM, M., HOSSAIN, MY., WAHAB, MA., AHAMED, ZD., ALAM, MJ., SHAH, MMR. and JASMINE, S., 2007. Effects of iso-nutrient fertilization on plankton production in earthen ponds of Bangladesh. Pakistan. Journal Biological Sciences, vol. 10, no. 8, p. 1221-1228.

BHUIYAN, AS., ISLAM, MT. and SHARMEEN, R., 2008. Occurrence and abundance of some copepods in a fish pond in Rajshahi, Bangladesh in relation to the physico-chemical conditions. Journal of Bioscience, vol. 16, p. 115-119.

BICUDO, CEM. and BICUDO, DC., 2004. Amostragem em limnologia. São Carlos: Rima. 351 p.

DAVIES, OA., ABOWEI, JFN. and OTENE, BB., 2009. Seasonal abundance and distribution of plankton of Minichinda stream, Niger Delta, Nigeria. American Journal of Science Research, vol. 2, no. 2, p. 20-30

GOLTERMAN, HL., CLYMO, RS. and OHNSTAD, MAM., 1978. Methods for physical and chemical analysis of fresh water. $2 \mathrm{ed}$. Oxford: Blackwell Scientific Publication. 213 p.

KONSOWA, AH., 2007. Ecological studies on fish farms of El-Fayom depression (Egypt). Egyptian Journal of Aquatic Research, vol. 33, no. 1, p. 290-300.

KOROLEFF, F., 1976. Determination of nutrients. In: GRASHOF, E. and KREMLING, E. (eds). Methods of seawater analysis. German: Verlag Chemie Wenhein. p. 117-181.

KYEWALYANGA, MS. and MWANDYA, AW., 2004. Influence of environmental variables on planktonic and phytobenthonic communities in earthen ponds at Makoba, Zanzibar. Western Indian Ocean Journal of Marine Science, vol. 3, no. 2, p. 123-133.

LOBO, E. and LEIGHTON, G., 1986. Estructuras comunitarias de las fitocenosis planctonicas de los sistemas de desembocaduras de ríos y esteros de la zona central de Chile. Revista Biologia Marina, vol. 22, no. 1, p. 1-29.

NUSCH, EA., 1980. Comparison of different methods for chlorophyll and phaeopigments determination. Archive für Hydrobiolgie, vol. 14, p. 4-36. 
ODUM, EP. and BARRET, GW., 2007. Fundamentos de ecologia. São Paulo: Thomson Learning. 612 p.

OKOJIN, VA. and OBI, AW., 1999. Effects of three fertilizer treatments on zooplankton productivity in plastic tanks. Indian Journal of Animal Science, vol. 69 , no. 5 , p. 360-363.

PEREIRA, E., ANNE, I., FIDALGO, ML. and VASCONCELOS, V., 2001. Phytoplankton and nutrient dynamics in two ponds of the Esmoric wastewater treatment plant (Northern Portugal). Limnética, vol. 20, no. 2, p. 245-254.

SAMPAIO, EV., ROCHA, O., MATSUMURATUNDISI, T. and TUNDISI, JG., 2002. Composition and abundance of zooplankton in the limnetic zone of seven reservoirs of the Paranapanema River, Brazil. Brazilian Journal of Biology, vol. 6, no. 3, p. 525-545.

SANTEIRO, RM., PINTO-COELHO, RM. and SIPAÚBA-TAVARES, LH., 2006. Diurnal variation of zooplankton biochemical composition and biomass in plankton production in tanks. Acta Scientiarum Biological Science,vol. 28, no. 2, p. 103-108.

SHANNON, CE. and WEAVER, W., 1963. The mathematical theory of communication. Urbana: University of Illionois Press. $144 \mathrm{p}$.

SIEGEL, S., 1975. Estatística não paramétrica (para ciências do comportamento). São Paulo: Mc Graw-Hill do Brasil. 350 p.

TANIGUCHI, GM., BICUDO, DC. and SENNA, PAC., 2005. Gradiente litorâneo-limnético do fitoplâncton e ficoperifiton em uma lagoa de planície de inundação do rio Mogi Guaçu. Revista Brasileira de Botânica, vol. 28, no. 1, p. 137-147.

VEGA, C., JAMBRINA, C., SAJA, R., BECARES, E., FERNÁNDEZ, C. and FERNÁNDEZ, M., 2007. Aspectos limnológicos de estanques para la producción intensiva de tenca (Tirica tinca). Limnética, vol. 26, no. 1, p. 173-182.

Received: 01 September 2009 Accepted: 14 May 2010 